3.Odintsov A. I. quaestio de intensification doctrina processus in hodierna paedagogica scientia. - Text: dirige // Young scientist. - 2015. - № 3 (83). - Pp. 829-831. - URL: https://moluch.ru/archive/83/15174//. ISSN: 2072-0297. eISSN: 2077-8295. - articulus a eros

4. Abdulaeva $R$. et al. Animi et paedagogica vitae actualizing practica intentionem educational environment in academia //RevistaEspacios. - 2017. - T. 38. - №. 40.ISSN 0798 1015-dictum a eros

5. Tskvitaria T.A. Vospitatelny potentsii tekhnologii obucheniya $v$ sotrudnichestvo [Educational potentia cognita vitae in cooperationem]. - 2016. - №. 4-3. - Pp. 420-423. UDC378. 147 - articulus ex acta

6. Bobrova N.G. Aspectus applicationem cognita technology in cooperationem ordinationem practica opera alumni ad studia lectiones. - 2014. Pp. 600-621. - URL: http://e-koncept.ru/2014/14179.htm. - ISSN 2304-120X. - articulus ex acta

7. Polat E.S. Novum paedagogica notitia vitae in educationis ratio. - M.: Publishing Center "Academia", 2009. P. 272. ISBN: 978-5-7695-6156-6. - librum

8. Cebrián F.J., Moreno J.J., Rodríguez M.G L. (2014) Cooperantem cognita in superiorum: differentia perceptiones confert ad coetus [Aprendizajecooperativoeneducación superior: diferenciasen la percepción de la contribución al grupo] //RUSC. Universitates et Scientia Societatis Acta. Vol. 11. - №. 2. - Pp. 70-84. http://dx.doi.org/10.7238/rusc.v11i2.1936. ISSN 1698-580X. - articulus ex diario-6156-6. - librum

9. Johnson D.W., Johnson R.T. Doctrina simul et solus: Cooperantem, auctor, et singulos cognita. Prentice-Hall, Inc, 1987. - Pp. 80-85. - librum

10. Fraile C.L. (1997) Ad intelligentiam cooperantem cognita // Acta Psychodidactics [Haciaunacomprensión del aprendizajecooperativo //Revista de psicodidáctica]. №. 4. - Pp. 59-76. ISSN: 1136-1034. - articulus a eros

11. Domingo J. (2008) Cooperantem cognita //Social operis quaternos [El aprendizaje cooperativo //Cuadernos de trabajo socialis]. Vol. 21. - Pp. 231-246.ISSN: 0214-0314. - articulus a eros

12. Sharon I., Sharon S. (1992) Crescentem cooperantem cognita per coetus quaestionem. - Lugduni: Doctores Collegii Press. T. 1234. - Pp. 14-21. - articulus a eros

13 Brush T.A. (1998) Embedding cooperative learning into the design of integrated learning systems: Rationale and guidelines //Educational Technology Research and Development. T. 46. - №. 3. - C. 5-18. Doi:10.1007/bf02299758. ISSN 1042-1629. - статья из журнала

14 Slavin R.E. (1983) When does cooperative learning increase student achievement? //Psychological bulletin. T. 94. - №. 3. - C. 429. Doi:10.1037/0033-2909.94.3.429.

15 Strategies E.I. Research Corner: Education Data and Research Analysis from Edvantia //Retrieved Nov. (2005) T. 15. - C. 2013.

16 Raviv A., Cohen S., Aflalo E. (2019) How should students learn in the school science laboratory? The benefits of cooperative learning //Research in Science Education. T. 49. - №. 2. - C. 331-345. Doi:10.1007/s11165-017-9618-2. -

\title{
МРНТИ 14.07.07.
}

\section{https://doi.org/10.51889/2020-4.1728-5496.24}

\author{
М.О. Еликбаева ${ }^{l}$, Н.К. Ахметов ${ }^{l}$
}

${ }^{I}$ Абай атындагы Қазақ ұлттық педагогикалық университеті, Алматы қ., Қазақстан

\section{БИОЛОГИЯНЫ ОҚЫТУДАҒЫ ОЙЫН ТЕХНОЛОГИЯСЫ}

\author{
Аң̧датпа
}

Сабақта мұғалімдер мен білім беру ұйымдарының алдына қойылған оқытудың негізгі мақсаттары мен міндеттері іске асырылады. Бұл сұрақтардың көпшілігін шешу бірінші кезекте оқытушы мен оқушылардың сабақтардағы бірлескен жұмысына байланысты. Сондықтан қазіргі заманғы білім беру жүйесі, әсіресе оқытудаға жаңа технологияларды, оның ішінде оқытудың ойын технологияларын тарту саласыда елеулі өзгерістерге ұшырады. Олар сабақта оқушылардың ойлау, шығармашылық және т.б. қызметінің белсенділігін арттырады. Бұл ретте сабақтың мазмұны өзгереді, ұсынылған ойын технологиясы аясында бірінші орынға оқушылар мен мұғалімнің бірлескен ойын қызметі тұрады. Мұндай 
қолайлы жағдайлар оқушыларды мақсатты түрде оқытуға мүмкіндік береді, бұл өз кезегінде олар үшін аса маңызды: оқу материалын сын тұрғысынан ойлау, талдау және синтездеу, проблеманы шешу құралдарын іздеу, ұжымда жұмыс істеу, жұмыс нәтижелерін түзету және т.б. қасиеттерді қалыптастырады.

Түйін сөздер: ойын, іс-әрекет, тұлға, психология, технология, тірі ағзалар, ақыл-ой.

\author{
M.Yelikbayeval ${ }^{1}$, N. Akhmetov ${ }^{l}$ \\ ${ }^{1}$ Abai Kazakh national pedagogical university, \\ Almaty, Kazakhstan
}

\title{
GAME TECHNOLOGIES IN LEARNING BIOLOGY
}

\begin{abstract}
The main goals and learning objectives set for teachers and educational organizations implemented in the lessons. The solution of most of these issues directly depends on the cooperative work of the teacher and students in the classroom. Therefore, the modern education system has undergone significant changes, especially in the field of attracting new technologies to learning, including game-based learning technologies. They increase the activity of students ' mental, creative, and other activities in the classroom. At the same time, the content of the lesson changes, and in the framework of the proposed game technology, the cooperative game activity of students and teachers comes to the fore. Such favorable conditions allow for purposeful learning of students, which, in turn, forms their most important qualities: critical thinking, analysis and synthesis of educational material, search for solutions to problems, teamwork, correction of work results, etc.
\end{abstract}

Keywords: game, activity, personality, psychology, living organisms, mental.

\author{
М.О. Еликбаева ${ }^{l}$, Н.К. Ахметов ${ }^{1}$ \\ ${ }^{1}$ Казахский национальный педагогический университет илени Абая, \\ 2. Алматы, Казахстан
}

\section{ИГРОВЫЕ ТЕХНОЛОГИИ В ОБУЧЕНИИ БИОЛОГИИ}

\section{Аннотация}

На уроке реализуются основные цели и задачи обучения, поставленные перед учителями и организациями образования. Решение большинства этих вопросов, в первую очередь, зависит от совместной работы преподавателя и учащихся на уроках. Поэтому современная система образования претерпела существенные изменения, особенно в области привлечения в обучение новых технологий, в том числе игровых технологий обучения. Они повышают активность мыслительной, творческой и др. деятельности учащихся на уроке. При этом меняется содержание урока, в рамках предложенной игровой технологии на первое место выходит совместная игровая деятельность учащихся и учителя. Такие благоприятные условия позволяют целенаправленно обучать учащихся, что, в свою очередь, формирует у них важнейшие качества: критическое мышление, анализ и синтез учебного материала, поиск средств решения проблемы, работа в коллективе, коррекция результатов работы и др.

Ключевые слова: игра, деятельность, личность, психология, живые организмы, мственный.

Кіріспе. Біздің жүйе жағдайында мектеп және колледж оқушылары үшін оқытудың негізгі түрі сабақ болып табылады. Сабақта мұғалімдер мен білім беру ұйымдарының алдына қойылған оқытудың негізгі мақсаттары мен міндеттері іске асырылады. Бұл сұрақтардың көпшілігін шешу бірінші кезекте оқытушы мен оқушылардың сабақтардағы бірлескен жұмысына байланысты. Сондықтан қазіргі заманғы білім беру жүйесі, әсіресе оқытудаға жаңа технологияларды, оның ішінде оқытудың ойын технологияларын тарту саласыда елеулі өзгерістерге ұшырады. Олар сабақта оқушылардың ойлау, шығармашылық және т.б. қызметінің белсенділігін арттырады. Бұл ретте сабақтың мазмұны өзгереді, ұсынылған ойын технологиясы аясында бірінші орынға оқушылар мен мұғалімнің бірлескен ойын қызметі тұрады. Мұндай қолайлы жағдайлар оқушыларды мақсатты түрде оқытуға мүмкіндік береді, бұл өз кезегінде олар үшін 
аса маңызды: оқу материалын сын тұрғысынан ойлау, талдау және синтездеу, проблеманы шешу құралдарын іздеу, ұжымда жұмыс істеу, жұмыс нәтижелерін түзету және т.б. қасиеттерді қалыптастырады.

Сонымен қатар, педагогика ғылымдарында ойын технологиялары қолданылады, дегенменен өте сирек. Мысалы, химия бойынша орта және жоғары оқу орындарында оку ойындарын қолдану мүмкіндігі Н.К. Ахметовтың еңбектерінде жуырда ғана кеңінен баяндалды [1,2, с. 368-400]. Сабақта, ойын технологияларын қолдану экологияны оқытуда жиі қолданылады және Кавтараздың алдыңғы жұмыстарында осындай мысалдар [3, с.67] бойынша тиісті ғылыми және әдістемелік әдебиеттерде бар.

Педагогикада оқу мақсатында ойын технологияларын қолдану да кеңінен таралған. Әсіресе, бұл орта оқу орындары мен колледждерге қатысты. Бұл биологияның медицина, биотехнологиялар, ауыл шаруашылығы салалары және т.б. үшін негізгі теориялық база болып табылатындығымен байланысты. Сондықтан да биологияны оқыту жаңа заманауи технологияларды қолдануды талап етеді.

Бірақ та педагогика өте алуан түрлі, көп пәннен құралған ғылым. Сондықтан оқыту талаптарына сәйкес келетін оқу ойындарын құру біздің ойымызша, барынша күрделі көп деңгейлі міндет болып табылады. Ең қарапайым бастапқы деңгейде, педагогиканың кез -келген пәні үшін, оқу ойынын құру оқу бағдарламасының жекелеген, жергілікті сұрақтарын таңдап, содан кейін осы сұрақтарға сәйкес оку ойындарын құруға болады.

Осыдан кейін оқу ойындары жоғары деңгейде биологияның негізгі бөлімдерін пәнаралық білімге үйрету үшін құрастырылады. Осының барлығы оқытушыдан тек қана биология пәнінің жақсы білімін ғана емес, сонымен қатар оқытудың ойын технологияларында үлкен рөл атқаратын психологиялықпедагогикалық білімді талап етеді. Оқытушының оқу ойынын қолдануға дайындайтынын осы ретпен көруге болады. [4, с.24]. Ең алдымен ол оқу материалынан оқушылардың білімі үшін ең қажеттісін таңдап, оны ойын формасына ауыстыру мүмкіндігін қарастырады. Бұл ретте оқу ойындарын олардың оқу мазмұнының маңыздылығы бойынша талдау өте маңызды. Окушылардың білімі мен іскерлігін жоғары сапалы деңгейде көтере алатын және қолдайтын ойындар мен оларды қолдану технологияларына ерекше көңіл бөлу керек. Оқыту үшін таңдап алынған оқу материалын ойын формасына аудару өте күрделі, бірақ көбінесе мүмкін болады. Мұндай мүмкіндік биологияда келесі мысалда көрсетіледі.

Зерттеу әдістері және әдіснамасы. Жер шарында қазіргі уақытта тірі ағзалардың бір жарым миллионға жуық түрі табылғандығы барлығына мәлім. Сонымен қатар, көптеген биологтар бұл санды кем дегенде бірнеше есе арттыруға болады деп санайды. Әрине, ағзалардың мұндай саны бары түсінікті және дұрыс жіктеуді талап етеді. Жалпы қолдануға ыңғайлы болу үшін талдау объектілерін қандай да бір ортақ қасиеттер негізінде бөлуді, яғни шартты топтар бойынша жіктеу деп түсінуге болады. Сондықтан ағзалардың үлкен саны үшін тиісті жіктеуді құру жауапты және қиын міндет болып табылады. Мұндай әрекеттер биологтармен бұрыннан бері жүзеге асырылды, бірақ та жіктеудің негізі сол кезде пайда болған жеке мақсаттар мен практикалық міндеттердің мәселелерін түсіндіруге арналған. Осыған байланысты XX ғасырдың ортасына дейін ұсынылған барлық жіктеулер негізінен жасанды сипатқа ие болды, онда негізге бір немесе бірнеше жеңіл ажыратылатын белгі алынды. Мысалы, Линнеем барлық ағзаларды екі патшалыққа бөлуді - жануарлар патшалығы мен өсімдіктер патшалығы деуді ұсынды. Жаңбыр құртынан жыланға дейінгі барлық құрттәрізділерді бір топқа біріктіруді ұсынды.

Биология ғылымның дамуы барысында ағзалар арасындағы табиғи өзара байланыстарға негізделген белгілерден жіктелуді құру көп пайдаланылды. Сондықтан да, анатомияда, физиологияда, морфологияда, биохимияда, жасушалық құрылыста, эмбриогенезде, мінез-құлықта сыртқы және ішкі ұқсас белгілер ескеріле бастады. Бұл эволюциялық өзара байланыстардың аса маңызды рольін атқарады. Осы сыртқы және ішкі белгілердің барлығын салыстыру 1982 жылы Маргелис пен Шварцқа тірі ағзалардың жүйесін (жіктелуін) ұсынуға мүмкіндік берді. Қазіргі уақытта бұл жүйе кеңінен мойындалды және оны биология негіздерін оқыту кезінде қолдануға кеңес береді. Сондықтан оның негізінде биология бойынша оқу ойынын жасау осы мақаланың авторлары үшін қосымша ғылыми, педагогикалық және әдістемелік қызығушылық тудырды. Мақала мәтіні бойынша әрі қарай редакциялық ыңғайлылық мақсатында жүйе авторлар ретінде емес, жіктеу анықтамасы бойынша қолданылады. 


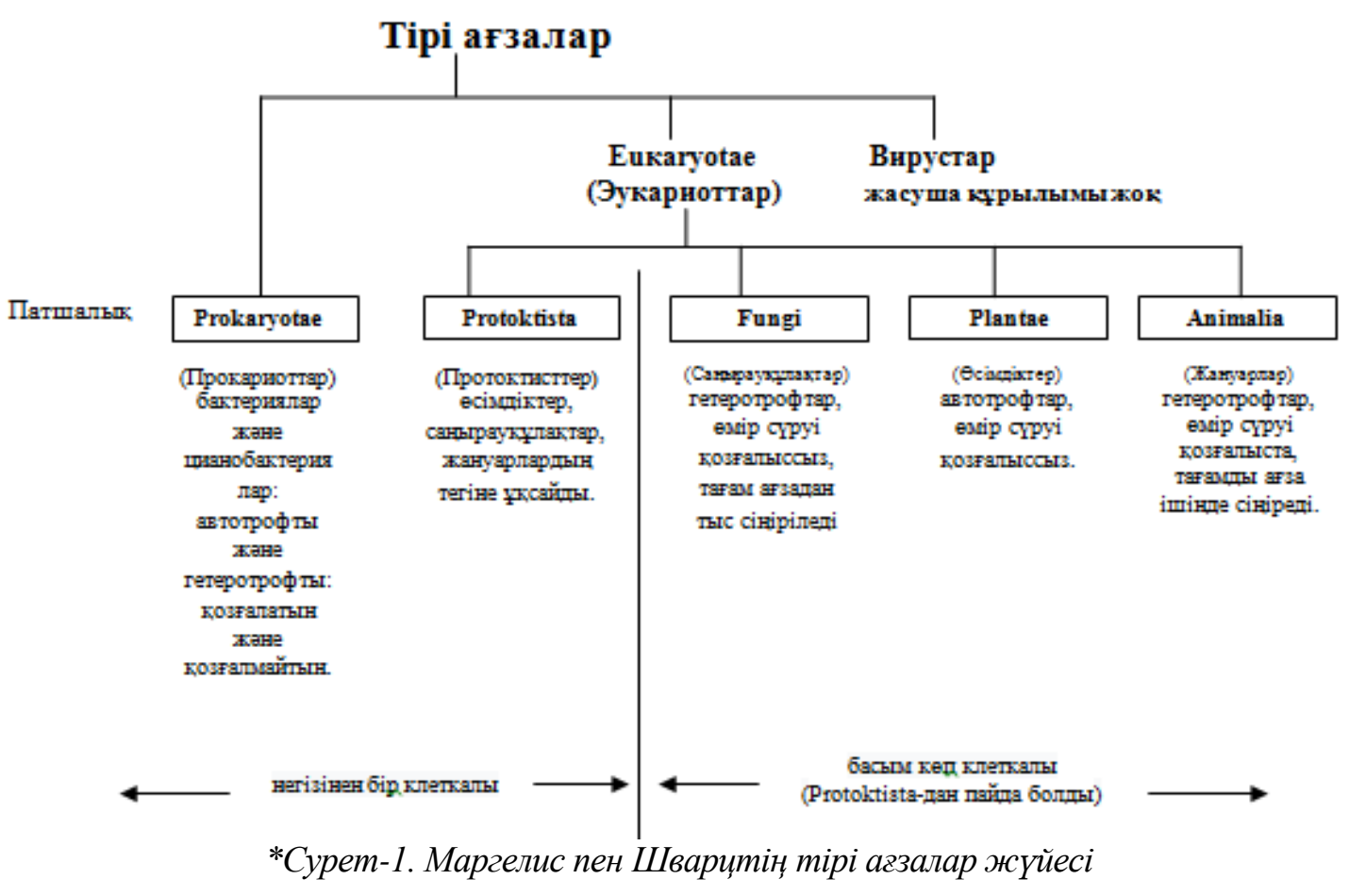

Маргелис пен Шварцтің жіктелуі негізінде (1-суретті қараңыз) сыртқы және ішкі ұқсас белгілерді салыстырудан басқа қазіргі кездегі тірі ағзалар арасындағы эволюциялық қарым-қатынас жатыр. Бұл ағзалардың эволюциясы бір жасушадан көп жасушаға, яғни күрделіліктің жоғарылауымен құрастырылған. Мұның барлығы оқу ойынын дайындау кезінде екі жақты сипатқа ие. Бір жағынан кіріспе деректердің (белгілердің) көп саны қойылған мақсатты іске асыруды қиындатуы мүмкін, ал екінші жағынан тиісті ойындарды құру және олар үшін ойын ережелерін анықтау кезінде осы іске асыру үшін мүмкіндіктер санын ұлғайтады.

Маргелис пен Шварц жүйесі бойынша тірі ағзаларды жіктеуге арналған оқу ойынын жасаудың бірінші кезеңінде біз құрылған ойынның көмегімен шешу қажет болатын негізгі міндеттерді анықтадық. Оларды екі негізгі топқа бөлуге болады, олар өз мәні бойынша бір-біріне тең болды. Бірақ олар мазмұны жағынан өзара тығыз әрекетті сақтай отырып ерекшеленді. Осы топтардың бірі оқу ойынын өткізу психологиялық-педагогикалық жағынан қамтамасыз ету болып табылады. Жасалатын ойын мүмкіндігінше осы ойындарға қойылатын талаптарға қатаң сәйкес болуы тиіс, ол туралы бұрынғы жұмыста көрсетілген. Осы оқу ойынына оқыту үшін бізге бөлінген оқу тапсырмаларын объектілер ретінде іріктеп енгізу де аса маңызды болды. Осы міндеттердің қатарына мыналар жатқызылды:

- оқушыларды ағзаларды жүйелеп оқыту қажеттілігі, өйткені жүйелеу негізінде ағзалардың бірбірімен ұқсастығы мен айырмашылықтары жатыр;

- биологтардың кеңінен танылуына және таралуына ие болған Маргелис пен Шварц жүйесіне окушыларды оқыту қажеттілігі;

- оқушыларды осы жүйеде қабылданған патшалықтардың орыс және латын атауларына оқыту қажеттілігі;

- оқушыларды патшалықтың жіктеуіндегі әрбіріне тән ерекше белгілерді бөлуге үйрету қажеттілігі;

- оқушыларды тірі ағзалардың бір жасушалығын көп жасушалықтан айыру қабілеті бойынша оқыту қажеттілігі.

Әрине, бір оқу ойындары аясында жоғарыда қойылған барлық міндеттерді толық шешу қиын, бірақ оған мақсатталған тәсілдерді анықтау және бөліп көрсетуге толық мүмкіндік бар.

Сурет-1. Маргелис пен Шварцтің тірі ағзалар жүйесі

Зерттеу нәтижелері. «Тірі ағзалардың жіктелуі» шартты атауын алған оқу ойынын біз ары қарай ұсынамыз.

«Тірі ағзаларды жіктеу» оку ойыны оқушыларды бірыңғай биологтардың көпшілігімен қабылдаған, оқытудың әртүрлі сатыларын, тірі ағзаларды шартты түрде бөлінген топтар бойынша бөлу туралы білімдерді жіктеуге арналған. Мұндай бөлу тірі ағзаларға ұқсас және әртүрлі белгілерге негізделген, бұл оқушылардың дайындық деңгейінің сапасын есепке алатын ойын жасауға мүмкіндік береді. Ойын жасау 
үшін жоғарыда айтылғандай, Маргелис пен Шварцтің тірі ағзаларының жүйесі қолданылады (1-суретті қараңыз).

Ойын ережелері. Ойын Маргелис және Шварц жүйесінің сипатын сақтайтын ойын үшін арнайы сызылған алаңда өткізіледі (2-сурет). Сондықтан 2-сурет осы жіктеменің құрамдас бөліктерімен салыстырмалы толтырылған түрде келтірілген. Дегенмен, ойынның өзі әрине, ойын үшін сол уақытта мүлдем бос алаңды толтырудан басталады. Сондықтан, 2-суреттегі патшалықтар мен вирустар туралы мәліметтер ойынның өзін дұрыс пайдалану үшін көмекші материал болып табылады. Бұл үшін 2суреттегі патшалықтар мен вирустар өкілдерінің белгілері, және патшалар мен вирустардың атаулары жеке дайындалған карточкаларда, ойын үшін алаңдардың тиісті бөлімдеріне кіретін өз өлшемдері бойынша орналастырылады. Мұндай карточкалардың мысалын 3-суретте көруге болады.

\begin{tabular}{|c|c|c|c|c|c|}
\hline \multicolumn{6}{|c|}{ Тірі ағзалар } \\
\hline \multirow[t]{2}{*}{ Вирустар } & \multirow{2}{*}{$\begin{array}{c}\text { Prokaryotae } \\
\text { (Прокариот- } \\
\text { тар) }\end{array}$} & \multicolumn{4}{|c|}{ Euкaryotae (Эукариоттар) } \\
\hline & & $\begin{array}{c}\text { Protoktista } \\
\text { (Протоктист- } \\
\text { тер) }\end{array}$ & $\begin{array}{c}\text { Fungi } \\
\text { (Саңыраукұлақ- } \\
\text { тар) }\end{array}$ & $\begin{array}{c}\text { Plantae } \\
\text { (Өсімдіктер) }\end{array}$ & $\begin{array}{c}\text { Animalia } \\
\text { (Жануарлар) }\end{array}$ \\
\hline $\begin{array}{c}\text { - жасуша } \\
\text { құрылымы } \\
\text { жоқ }\end{array}$ & $\begin{array}{c}\text { - көбінесе бір } \\
\text { жасушалы }\end{array}$ & $\begin{array}{c}\text { - көбінесе бір } \\
\text { жасушалы }\end{array}$ & $\begin{array}{c}\text { - көбінесе көп } \\
\text { жасушалы }\end{array}$ & $\begin{array}{c}\text { - көбінесе көп } \\
\text { жасушалы }\end{array}$ & $\begin{array}{c}\text { - көбінесе көп } \\
\text { жасушалы }\end{array}$ \\
\hline $\begin{array}{c}\text { - 1,2 млрд. } \\
\text { жыл } \\
\text { уақыттан } \\
\text { бұрын }\end{array}$ & $\begin{array}{c}\text { - 3,5 млрд. } \\
\text { жыл бұрын } \\
\text { пайда болған }\end{array}$ & $\begin{array}{l}\text { - 1,2 млрд. } \\
\text { жыл бұрын }\end{array}$ & $\begin{array}{c}\text { - 1,2 млрд. жыл } \\
\text { бұрын }\end{array}$ & $\begin{array}{c}\text { - 1,2 млрд. жыл } \\
\text { бұрын }\end{array}$ & $\begin{array}{l}\text { - 1,2 млрд. } \\
\text { жыл бұрын }\end{array}$ \\
\hline $\begin{array}{l}\text { - облигация- } \\
\text { лық } \\
\text { эндопара- } \\
\text { зиттер }\end{array}$ & $\begin{array}{c}\text { жасуша } \\
\text { диаметрі } \\
\text { 0,5-10 мкм }\end{array}$ & $\begin{array}{c}\text {-жасуша } \\
\text { диаметрі } \\
\text { 10-100 мкм }\end{array}$ & $\begin{array}{c}\text { - } \\
\text { жасушадиаметрі } \\
\text { 10-100 мкм }\end{array}$ & $\begin{array}{c}-- \\
\text { жасушадиаметрі } \\
\text { 10-100 мкм }\end{array}$ & $\begin{array}{c}\text {-жасуша } \\
\text { диаметрі } \\
\text { 10-100 мкм }\end{array}$ \\
\hline $\begin{array}{c}\text {-ерекшелі-гі } \\
\text { жоғары }\end{array}$ & $\begin{array}{l}\text { және } \\
\text { гетеротроф ты }\end{array}$ & $\begin{array}{c}\text { - автотрофты } \\
\text { және гетеро- } \\
\text { трофты }\end{array}$ & - гетеро-трофты & - автотрофты & $\begin{array}{c}\text { - гетеро- } \\
\text { трофты }\end{array}$ \\
\hline & $\begin{array}{c}\text {-жылжыма-лы } \\
\text { және } \\
\text { жылжымай- } \\
\text { тын }\end{array}$ & $\begin{array}{l}\text { - жылжымалы } \\
\text { және } \\
\text { жылжымай- } \\
\text { тын }\end{array}$ & $\begin{array}{c}\text {-жылжымай- } \\
\text { тын }\end{array}$ & $\begin{array}{c}\text { - жылжымай- } \\
\text { тын }\end{array}$ & $\begin{array}{l}\text { - жылжымалы } \\
\text { және } \\
\text { жылжымай- } \\
\text { тын }\end{array}$ \\
\hline & $\begin{array}{l}\text { - азотты } \\
\text { бекітуге } \\
\text { қабілетті }\end{array}$ & $\begin{array}{l}\text { - азотты } \\
\text { бекітуге } \\
\text { қабілеттілігі } \\
\text { жоқ }\end{array}$ & $\begin{array}{l}\text { - азотты } \\
\text { бекітуге } \\
\text { қабілеттілігі } \\
\text { жоқ }\end{array}$ & $\begin{array}{l}\text { - азотты } \\
\text { бекітуге } \\
\text { қабілеттілігі } \\
\text { жоқ }\end{array}$ & $\begin{array}{l}\text { - азотты } \\
\text { бекітуге } \\
\text { қабілеттілігі } \\
\text { жоқ }\end{array}$ \\
\hline & $\begin{array}{c}\text { - жасуша } \\
\text { қабырғалары } \\
\text { қатты }\end{array}$ & $\begin{array}{c}\text { - жасуша } \\
\text { қабырғалары } \\
\text { қатты }\end{array}$ & $\begin{array}{c}\text { - жасуша } \\
\text { қабырғалары } \\
\text { қатты }\end{array}$ & $\begin{array}{l}\text { - жасуша } \\
\text { қабырғалары }\end{array}$ & $\begin{array}{c}\text { - жасуша } \\
\text { қабырғалары }\end{array}$ \\
\hline & $\begin{array}{c}\text { - қарапайым } \\
\text { жартысынан } \\
\text { жасушалар } \\
\text { бөлінеді }\end{array}$ & $\begin{array}{c}\text { - митоз, мейоз } \\
\text { немеле } \\
\text { олардың } \\
\text { ұқсастық- } \\
\text { тары }\end{array}$ & $\begin{array}{c}\text { митоз, мейоз } \\
\text { немеле олардың } \\
\text { ұқсастықтары }\end{array}$ & $\begin{array}{c}\text { - митоз, мейоз } \\
\text { немеле олардың } \\
\text { ұқсастықтары }\end{array}$ & $\begin{array}{c}\text { - митоз, мейоз } \\
\text { немеле } \\
\text { олардың } \\
\text { ұқсастық- } \\
\text { тары }\end{array}$ \\
\hline & $\begin{array}{c}\text { - хлоро- } \\
\text { пласттар жоқ }\end{array}$ & $\begin{array}{c}\text { - фотосинтез } \\
\text { хлоропластта } \\
\text { жүреді }\end{array}$ & & $\begin{array}{c}\text { - фотосинтез } \\
\text { хлоропластта } \\
\text { жүреді }\end{array}$ & \\
\hline
\end{tabular}


Абай атындавы ҚазҰПУ-н ХАБАРШЫСЫ «Педагогика вылымдары» сериясы, № 4 (68), 2020 ж.
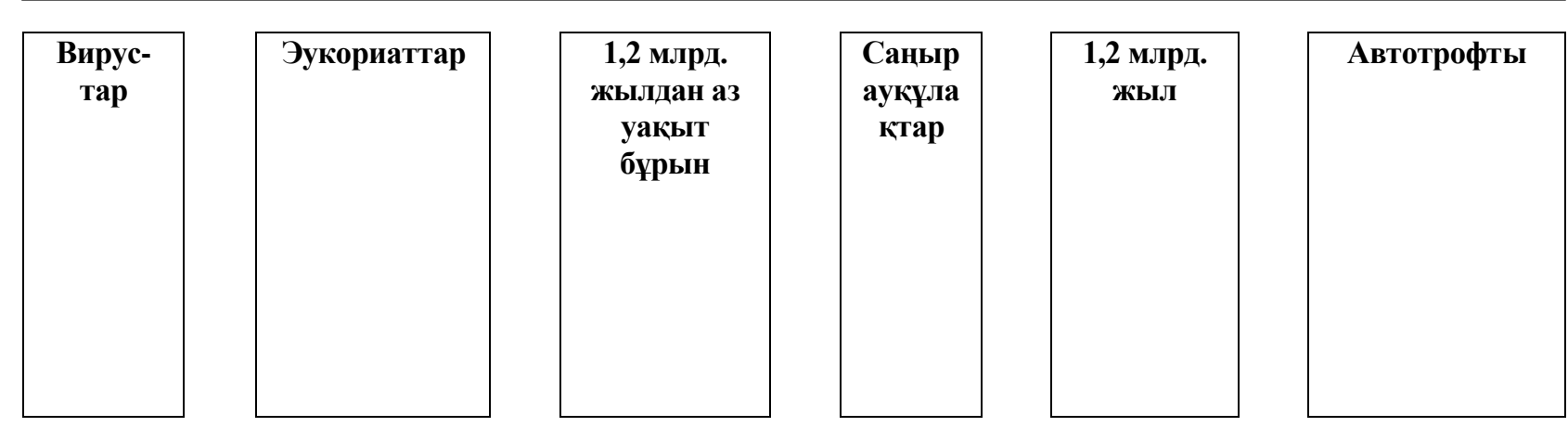

Сурет-2. «Тірі авзалардың жіктелуі» оку ойынына арналван карточкалардың үлгісі

2-суретте вирустар мен патшалықтар белгілері мұндай карточкаларға арналған орындар пунктирлік сызықтармен бөлінген. Карточкалар саны және олардың мазмұны ойынға қатысу үшін іріктелетін патшалық атауларының саны мен мазмұнына және олардың белгілеріне қатаң сәйкес келуі тиіс. Жоғарыда айтылғандар ойынға дайындықтың бірінші кезеңі болып табылады.

Ойынның екінші кезеңінде оқушылар ойынның ережелерімен тікелей танысады. Оку материалының көлеміне байланысты құрамында 4-6 ойыншыдан құралған топпен ойнауға ыңғайлы. Дайындалған карточкаларды ойыншылардың бірі, ойынға қатысушы оқушыларға шеңбер бойынша таратады. Ережеге сәйкес, бірінші болып өз карточкаларынан құтылатын ойыншылардың бірі ойын жеңімпазы болып саналады. Карточкаларды ойыншылар кезекпен, сағат тілі бойынша шығарады. Сонымен қатар, ойыннан карточкалардың өзін тікелей шығару келесі ережелер мен шарттарға байланысты:

Карточкаларды ойыннан шығару оларды шығарудың белгілі бір реттілігімен байланысты. Тиісті патшалықтың немесе вирустардың белгісі бар карточкаларды шығару, егер ойын алаңында осы патшалықтың немесе вирустардың атауы жазылған карточка қойылған жағдайда ғана жүргізілуі мүмкін. Ойын алаңында «eukaryotae» және «эукариоттар» жалпы карточкалары қойылған кезде ғана патшалық атауымен карточкаларды шығару мүмкін болады.

Кесте-1. «Тірі ағзалардың жіктелуі» оқу ойынына арналған кесте

Сурет-2. «Тірі ағзалардың жіктелуі» оку ойынына арналған карточкалардың үлгісі

Карточкаларды кезең-кезеңімен шығару алдымен ойыншыдан оның қандай да бір патшалыққа тиістілігін білуді, содан кейін оның белгілерін білуді талап етеді. Белгілі бір патшалықтың латын және орыс атаулары кезектілікті сақтамай қойылады;

- ойыншының бір жолы үшін ол карточканың беткі бөлігін жоғары қаратып, басқа ойыншыларға хабарлай отырып, тек бір карточканы шығаруға болады. Осыдан кейін жүру құқығы келесі сағат тіліне ауысады;

- жол жүру құқығы бар ойыншы, егер ол үшін мүмкіндік болса, оны жасауға міндетті. Мүмкіндік болмаған жағдайда ол бұл туралы басқа ойыншыларға хабарлайды, ал жүру құқығы келесі ойыншыға өтеді;

- қате жүргенде, қате жасаған ойыншы, қате салынған карточканы кері алып кетеді, ал жүру құқығы келесі ойыншыға ауысады. Қарсыластың қатесін байқаған оқушы ойыннан қосымша тағы бір карточканы шығару мүмкіндігіне ие болады;

- ойында оқытушы әдетте бас кеңесші және төреші;

- оқу ойыны ойыншылардың қолында карточкалар жоқ болғанға дейін, ойынның барлық алаңы толтырылғанға дейін жалғасады. Бұл ойын ережесі оқушылардың қажетті білімдерін толық меңгеру және танысу үшін қажет;

- бірінші жүріс құқығы Еикаrуotae және «эукариоттар» карточкалары бар ойыншыларға осы тәртіпте жүретін және тиісінше жүретін ойыншыларға беріледі.

Осылайша, жоғарыда келтірілген шарттар мен ережелерден ол жұмыста белгіленген ойын олардың кейбірін атап, оларға тимей-ақ, психологиялық-педагогикалық талаптарын толықтай қанағаттандырады. Осылайша, ойын алаңының тиісті бөлімдерін толтырудың қатаң белгіленген реттілігі, ойыншылардың бар ойын карточкаларының жиынтығына байланысты ойыншыларға ойынның барысы мен бағытын өзі үшін тиімді әсер етуге мүмкіндік береді. Бұл біздің ойында пайдаланылатын карточкалардың әртүрлі ойын құндылығына байланысты. Егер олардың ойын мүмкіндіктерін салыстырсақ, осы мүмкіндіктердің келесі иерархиясын құруға болады (4 суретті қараңыз). 

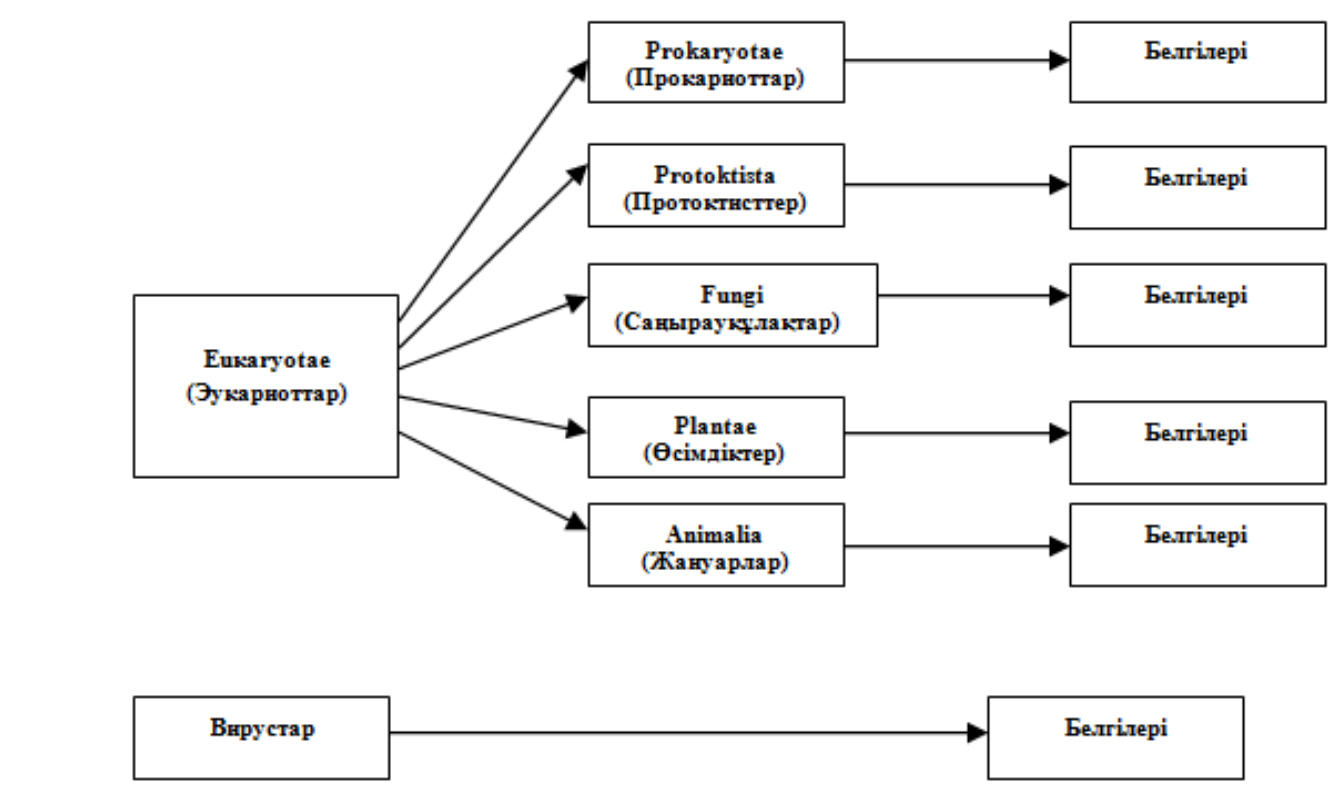

Мүмкіндігі көбірек

Мүмкіндігі азырақ

Сурет-3. «Тірі авзаларды жіктеу» ойынында иерархияны жүзеге асыру мүмкіндігі

Эукариоттың карточкасы барлық патшалықтар үшін жіктелуді құру мүмкіндігін ашады,ал олар өз кезегінде өзінің тиісті белгілері үшін ғана іріктеуге мүмкіндік береді. Сондықтан, латын және орыс тілдеріндегі вирустар мен патшалықтар карточкалары ең үлкен құндылыққа ие, содан кейін тиісті патшалықтар белгілері бар құндылығы төмен ойын карточкаларынан арылуға құқық береді. Патшалықтар карточкаларының болуы оқушыға - ойыншыға басқа ойыншылар үшін оны қиындата отырып, ойын барысын бағыттауға және реттеуге мүмкіндік береді. Бұл қасиет осы сөздің дұрыс түсіну үшін, сол ойынды, ойын ережелері үшін ұсынылған сипатты дұрыс түсіндіруі қажет. Окушыларды тірі ағзаларды жіктеу ойыны арқылы оқытудан басқа, оларды логикалық талдау, ойын тактикасы мен стратегиясын құра білу, сыни тұрғыдан ойлау, ұжымда жұмыс істей білу, дербестік және т.б. сияқты қажетті қасиеттерді дамытуға көмектеседі.

Пікірталас. Осы сәттерді жақсы түсіну үшін мысал ретінде 3-суретте көрсетілгендей, ойынға қатысушы оқушылардың біріне, карточкалар жиынтығымен пайда болуы мүмкін гипотетикалық жағдайды қарастырған ыңғайлы. 3 және 4 суреттерден көріп тұрғанымыздай, ойыншы әртүрлі мүмкіндіктерге ие болуы мүмкін. Егер бірінші қадамда ойыншылардың бірі айқын болса, бұл жағдайда біздің мысалдағы«eukaryotae» жазуы бар карточкасы бар ойыншы баруға тиіс, содан кейін басқа нұсқалар болуы мүмкін. Ойынның басқа қатысушыларының жүрісіне жауап ретінде ол екі жолмен жүре алады. Бірінші жол - бұл бірден вирус және Fungi патшалығы ойын карточкаларын енгізе алады. Екінші жолтиісті мүмкіндікті күту және басқа ойыншылардың қойған патшалық белгілері бар карточкаларынан арылуға тырысу. Алайда, басқа ойыншылардың осы патшалықтардың карточкаларын ойынға енгізгендігін күту керек. Сондықтан, ұту үшін оқушыға резервтегі маңызды карточканы сақтай отырып, мүмкіндігінше екінші жолды таңдау керек. Бірақ бұл жағдайда басқа нұсқа болуы мүмкін, өйткені біздің ойыншының қолында вирустар мен fungi патшалығы карточкалары бар. Олардың кез-келгенінің тиімділігі бірдей, бірақ бұл сіз ойлағандай емес. Бұл жалпы ойында «1,2 млрд жыл бұрын» 4 карточка бар және тек бір ғана «1,2 млрд жылдан бұрын пайда болған». Сондықтан fungi патшалығы ойын карточкаларын енгізу үшін басқа ойыншыларға осы патшалықтың осы белгісі бар карточканы енгізу мүмкіндігін береді. Сонымен қатар, вирустары бар карточкаларды ойынға енгізу үшін басқа ойыншыларға осы мүмкіндікті бермейді. Бірақ, ойыннан «1,2 млрд. жылдан бұрын пайда болған» карточкасын шығаруға мүмкіндік береді. Сондықтан бұл мүмкіндік нұсқалардың көптігіне байланысты осы оқу ойынына ерекше қосымша құндылық пен тартымдылық береді. 
Осы оқу ойынының ерекше артықшылықтарына оның көп деңгейлі әмбебаптығын жатқызуға болады. Оған мектеп және колледж оқушылары да, жоғары оку орындарының студенттері де және жоғары оқу орнынан кейінгі білім берудің тыңдаушылары да қатыса алады. Мұндай әмбебаптылық оның құрылымының ерекше икемділігімен байланысты, онда деңгей аралық өткелдерде қажетті бірізділік пен өзара байланыс сақталған. Ойынның бірінші деңгейінің негізі-тірі ағзаларды жіктеудің ең негізгі элементтерін білу. Мысалы, патшалардың жалпы атаулары, негізгі белгілер және т.б. Бұл деңгей орта оқу орындарының оку бағдарламаларына сәйкес келеді. Жоғары оку орындарының оқушылары үшін жоғары деңгей басталады. Олар үшін, таңдаған мамандығына байланысты, патшалықтың ерекше белгілерін арнайы таңдау арқылы деңгейдің күрделілігін оқытушы жоғарылатады. Бұл ретте оқытушыда осы белгілерді таңдауда кең мүмкіндік бар. Барлығы оқушылардың меңгеруі қажет оку бағдарламасына байланысты.

Қорытынды. Осылайша «тірі ағзаларды жіктеу» оку ойыны оқу процесінде көбірек пайдалану үшін ұсынылады. Өйткені оқытудан басқа, білімді бақылау мен бекітудің жақсы құралы бола алады. Жекелеген жағдайларда оқу ойынын оқу процесіне жаңа оқу материалын енгізумен ғана емес, басқа да тәсілдермен күрделене отырып енгізуге болады. Мысалы, оны ойын үшін бос алаңнан емес, тірі ағзалардың жіктеуінен алынған тиісті мәліметтермен толтыруды (2-суретті қараңыз) қолдануға болады. Бұл жағдайда оқушылар іздеу режимінде олардың карточкаларының мазмұнына сәйкес ойын алаңына тауып, оларға тиісті карточкаларын орналастыруы қажет болады. Көрінетін қарапайымдылыққа қарамастан, бұл нұсқаның өзіндік педагогикалық мағынасы бар, өйткені ойнаушы оқушы кез-келген жағдайда зерттелетін сыныптама туралы алғашқы білім алады. Сондай-ақ, ойын бағдарлауға, ойын алдындағы нұсқаларды таңдау, жағдайларды талдау және т.б. қосымша білім алады. Содан кейін оқу ойынын күрделендіре беруге болады және оны жүзеге асыру үшін бос алаңды толтырудан бастау керек.

Пайдаланылван әдебиеттер тізімі:

1. Грин Н.,Стаут У., Тейлор Д. Биология. Учебник. Под ред. Р. Сопера. - М.: Мир.,2007. - T. 1. - 368 c.

2. Борзова 3.В., Дидактические материалы по биологии: Методическое пособие. / 3.В. Борзова , А.М.Дагаев. - М.: ТЦ Сфера, 2005. - 400 с.

3. Долгая Т.И. Игровые технологии в учебном прочессе / Долгая Т.И. // Школа. 2004. №1. - С. 67.

4. Мальгина А.С. Игровые формы уроков биологии: метод. пособие / А.С. Мальгина. - Саратов: Аквариус, 1998. - 24 c.

References:

1. Viridis N., Pingues W., Taylor D. Biology. Artem. Edited by R. Soper. - M.: Mir.,2007. - Vol. 1. $368 p$.

2. Borzova Z.V., Didactic materia in biology: A applicando dux. / Z. V. Borzova, A. m. Dagaev. Moscow: Sfera Shopping Centrum, 2005. - 400 p.

3. Vestibulum vitae est in institutionis processu / Dolgaya T. I. // Schola. 2004. №1. - P. 67.

4. Malygina A.S. Ludum formae biology lectiones: modus. manibus / A. S. Malygina. - Saratov: Aquarius, 1998. -24 .

МРНТИ 14.35.01

https://doi.org/10.51889/2020-4.1728-5496.25

Г.К. Шолпанқұлова ${ }^{1}$, Д.Ж. Торвауым ${ }^{1}$

${ }^{1}$ Л.Н. Гумилев атындавы Еуразия ұлттық университеті,

Нұр-Сұлтан қ., Қазақ̆стан

\section{ӘЛЕУМЕТТІК ПЕДАГОГТЫН ДАРЫНДЫ БАЛАЛАРМЕН ЖУРГІЗЕТІН ЖҰМЫСТАРЫНЫН БАҒЫТТАРЫ}

Анудатпа 